Global Conferences Series:

Social Sciences, Education and Humanities (GCSSSEH), Volume 3, 2019

The $1^{\text {st }}$ International Conference on Education, Social Sciences and Humanities

DOI: https://doi.org/10.326/hum0211

\title{
The Contribution of Educational Psychology in Teaching Millenial Students
}

\author{
Muhammad Jufri ${ }^{1}$, Nur Aeni ${ }^{2}$ \\ 1,2Universitas Negeri Makassar \\ m.jufri@unm.ac.id
}

\begin{abstract}
The present paper is an attempt to know about the importance of educational psychology in making a better condition in teaching-learning process. The research was conducted at psychological faculty of Universitas Negeri Makassar. There were 60 students in the academic year 2017/2018 as the primary subjects of this research and there were two lecturers as well. The researcher conducted interviews to collect the data. The researcher focused on contribution and role of educational psychology in creating conducive teaching-learning environment in the classroom. Educational psychology is the applied knowledge gained from psychology uses in the classrooms. It is helpful in understanding the learners, learning process, instructional strategies and provides basis for the selection of appropriate methods, techniques, approaches, tools to satisfy and fulfil the need of learners that results in better learning. With the help of educational psychology teacher is able to create positive learning environment in the classrooms resulting in effective learning. The educational psychology plays an important role in making learning easy, joyful and interesting process for millennial students
\end{abstract}

Keywords: Educational Psychology, Conducive Learning Environment, millennial students

\section{Introduction}

Educational psychology is the applied branch of psychology and is the combination of education and psychology. The psychological principles, laws and techniques are applied to the development of educational strategies, teaching-learning situations, results/findings are applied in the field of education and it is concerned with the scientific study of human learning, including both cognitive and behavioral aspects. According to Skinner "educational psychology is the branch of psychology which deals with teaching and learning" (as cited in Kumari, Sundari and Rao, 2006).

Psychology is defined as a science which aims to give better understanding and control of the behavior of the organism as a whole. Skinner "psychology is the science of behavior and experience" (as cited in Kumari, Sundari and Rao, 2006). In the words of Fernald and Fernald (2004) "psychology is the science of behavior and experience; the science of the adjustments of organisms to their environment."

It is a scientific in approach that uses psychological constructs and tools to understand the various characteristics of learners, teachers, learning tasks, learning environment and educational settings

Copyright (C) 2019, the Authors. Published by Redwhite Press.

Page | 155

This is an open access article under the CC BY-NC license

(http://creativecommons.org/licenses/by-nc/4.0). 
interacting to modify or change behaviors of learners in school settings. According to Peel "educational psychology helps the teacher to understand the development of his pupils, the range and limits of their capacities, the process by which they learn and their social relationships" (as cited in Manichander, 2015). It provides information about the many factors that affect teaching-learning and offers useful and tested ideas for improving instruction. It is educational psychology which makes teachers effective. Give positive verbal/nonverbal reinforcement and corrective feedback to the learners. Communicate to students about expectations.

Educational psychology gives importance to learners in making classroom as social platform where exchange of ideas and healthy discussions among students and teachers takes place. It focuses on making the classroom environment conducive, conducive classroom is a catalyst in promoting a favorable learning environment to ensure effective teaching-learning. Teachers should strive to build a positive learning atmosphere where focus is on cooperation and collaboration rather than competition. Teacher should motivate learners to share their ideas and to seek clarification until they understand it properly.

The millennial students need a more relaxed learning environment and educators who provide the best strategy. They have the mobility and access of technology practically anywhere. As a teacher, prepare yourself to explore a lot of fun and enjoyable teaching methods, namely:

1. Use active learning approaches for participation

2. Explore the students ability

3. Facilitate the students to be more creative and active in teaching and learning process.

Teaching Millennials effectively does not mean we need to "friend" them on Facebook or start a thread on Twitter (although that might be an effective way of keeping in touch with them). It means to evaluate how we reach them and teach them both inside and outside the classroom. The traditional lecture mode of instruction may not be dead, but it does require retooling in this age of limited attention spans and increased emphasis on student engagement (Nevid, 2008).

\section{Method}

This paper applied descriptive qualitative research. The participants of the research were the second semester students of Psychological faculty at Universitas Negeri Makssar in academic year 2017/2018. The participants were 60 students and there were two lecturers from Universitas Negeri Makssar. The lecturers and the researcher performed deep discussion to get some input. The study used purposive sampling for the research.

\section{Results and Discussion}

\section{Role of Educational Psychology in Making Conducive Teaching-Learning Environment.}

Several researchers like Senge, Kleiner, Roberts, Ross and Smith (1994) explored that teachers are producers of environments that permits learner to learn. When learners are anxious, worried, stressed about making mistakes they are less likely to engage in their academic activities in an effortful, meaningful and strategic manner (Turner, Thorpe and Meyer, 1998). Educational psychology is necessary to create congenial environment which results in better learning. After careful perusal of studies we cannot ignore the role of educational psychology in providing conducive and congenial learning environment resulting in better retention and better academic achievement among learners.

Conflict management is a part of educational psychology which deals with the ability of individual to take decision or to choose most suitable situation between the two or more situations. "Psychological science has much to contribute to enhancing teaching and learning in the classroom," said Joan Lucariello, PhD, chair of the Coalition for Psychology in Schools and Education and a contributing author of the report. "Teaching and learning are intricately linked to social and behavioral factors of human development, including cognition, motivation, social interaction and communication." For instance, one of the principles outlined in the report makes clear that teachers' 
expectations about their students can affect students' motivation and learning outcomes. Most teachers' expectations are based on students' past performance and may be an accurate representation. In some cases, however, if an educator has an inaccurate perception of a student's abilities and communicates lower expectations (verbally or nonverbally), it could lead the student to perform in ways that confirm the faulty expectations and adversely affect the student's progress. To counteract this effect, the report recommends that teachers maintain high expectations of all students and check themselves regularly to make sure they are not treating students differently based on their expectations.

\section{Educational Psychology and Teaching-Learning Process}

Educational psychology has contributed considerably in the creation of teaching-learning environment. It helps the teacher in the following ways:

1. Stages of Development: As we know that human life passes through different stages of development before it reaches adulthood. They are: infancy, childhood, adolescence and adulthood. Each stage has its own characteristics. Psychologists have thoroughly studied the characteristic behaviour patterns of these different stages of life. Identification of these stages with different sets of characteristics, attributes and features regards physical, mental and emotional development greatly help educationists to design curriculum and determine appropriate methods of teaching-learning for learning at different stages. It is duty of teachers in bringing balanced growth and development in child's personality. One aspect of direction of growth should not be developed at the cost of others. There should be perfect harmony and balance between the different stages of growth. Knowledge of conflict management help teachers in providing effective instruction according to developmental stages is helpful to mould behaviour of learners.

2. Know Your Learner: Psychologists are concerned to establish the behaviour pattern of human behaviour so that they are able to know, predict and modify behaviour (Shiundu and Omulando, 1992). Learner is central in the teaching-learning process. Educational psychology helps the teacher to know about learning capacity, interest, attitudes, aptitudes, creativity, intelligence, covert-overt behaviour, motivation and the other acquired or innate capacities and abilities of the learners. It also helps to know the stages of development linked with social, emotional, intellectual, physical, mental and aesthetic needs, to know level of aspiration, conscious and unconscious behaviour, individual and group behaviour, conflicts, desires and other aspects mental health and hygiene. In this way guidance can be provided and positive attitude towards the learner on the part of the teacher can be developed.

3. Dealing with Diverse Learners: Educational Psychology helps the teacher to adapt and adjust his teaching according to the level and need of the diverse learners. For effective teaching-learning the teacher must have the knowledge of the various approaches, methods, principles, laws and factors affecting it. Then only he/she can apply diagnostic and remedial measures in the teachinglearning situation. Conducive teaching-learning environment can be achieved in this way. Respectful environment are also an important factor in enhancing/fostering problem solving ability among learners and understanding of concepts (Cohen, 1994) and (De Lisi and Golbeck, 1999).

4. Knowledge of Individual Differences: No two persons are exactly alike. Learners differ in their level of intelligence, aptitudes, attitude, interest, creativity etc. There are gifted, under achievers, slow learners, backward, differently able learners. Thus, educational psychology helps the 
teacher to know the individual differences among the learners in the class and the procedures accordingly, methodology and techniques can be adopted for them to deal with differences.

5. Dealing with Special Needs Learners: Special education means instructions that are specially designed to meet the unique needs of learners or the special needs children. The special needs children are the ones who need adapted teaching instructions, adapted learning environment or adapted learning process. They may be physically differently able or children with delinquency (juvenile delinquent). These children are identified and help teachers in selecting pedagogy which is suitable for them. Educational psychology helps these learners by providing educational services to these.

6. Tackling Classroom Problems: There are various problems in the classroom such as: truancy, bullying, peer pressure, cheating in tests, academic stress, academic anxiety etc. Educational Psychology equips the teacher by studying the characteristics of the children with problems, to know about the dynamics of the group, behavioral characteristics patterns, management of conflicts and adjustments. These techniques equip teachers to deal effectively with classroom problems for better teaching-learning environment in classroom.

7. Suitable Methods of Teaching: Educational Psychology helps educationists to discover various new approaches, principles, methods and techniques of teaching which are helpful in today's teaching-learning process. It helps the teachers to select appropriate teaching methods and how different activities like play, drama, skits, groups discussion, demonstrations, multimedia enabled teaching enhances the teaching level and how other innovative methods can turn learning into an interesting task.

8. Heredity and Environment of the Child: Educational psychology equips the teacher with knowledge that the child is the product of heredity and environment. They are the inevitable two sides of a single coin. Heredity and environment plays a central role in the all-round development of the child. The child is born with some innate hereditary qualities and interaction with environment helps them to be modified according to the requirements of the society.

9. Mental Health: Educational Psychology helps the teacher to know about the factors responsible for the mental ill-health and maladjustment of learners and to suggest improvements. Besides this, it also provides the teacher with necessary insight to improve his own mental status to deal with the situation effectively.

10. Need Based Curriculum: Curriculum is an integral part of the teaching-learning process. Curriculum should be learner-centered and fulfill the motives, psychological needs of the individual. Syomwene, Kitainge and Mwaka (2013) discussed the influences of psychology in the decision making process while constructing curriculum. It provides a basis for understanding of learners' needs, attitude, and teaching-learning process. It forms the basis for the methods, materials and activities of learning. Educational psychology helps the teacher to suggest ways and means to curriculum framers and administrators to prepare balanced curriculum which caters the diverse needs of the learners.

11. Guidance and Counseling: Guidance and counseling to a learner is needed because psychological abilities, aptitude, interests and learning styles differ from individual to individual. Similarly learners are given solutions to deal with their psychological, academic, vocational and personal problems which might affect their studies. Learners are able to develop problem solving ability which helps them to deal with particular issues concerning their lives. With the help of guidance and counseling teachers are able to guide and instruct learners to cope with different situations which they face in their school. Students who are guided and counseled in a right way tend to know what and how to do things by their teachers. . 
12. Assessment and Evaluation: Assessment and Evaluation utilizes data to improve teaching technique and academic program me. Assessment plays a major role in student learning and developing their motivation to learn. It is based on clear learning goals. Evaluation is a central part of the teaching-learning process. How to test the potentialities of the child depends upon the evaluation techniques. Student skill, knowledge, competency and ability are best measured with assessment processes based on psychological science with well-defined standards for quality and fairness. Formative and summative assessments need to be evaluated for both reliability and validity, helps teacher in proper assessment and evaluation of learners to know their understanding of subject. Teachers can improve the reliability and validity of formative and summative assessments by learning targets item analysis, discussing the results with other educators and monitoring and measuring outcomes for discrepancies across groups or subgroups of students. The development of the different types of psychological tests for the assessment and evaluation of the learner is a distinct contribution of educational psychology.

13. Self-Discipline: Earlier "spare the rod and spoil the child" was the philosophy prevailing in Indian classrooms. Flogging the child was the main instrument. Now repressive system is replaced by preventive system with the contribution of educational psychology. Now teachers adopt a cooperative, collaborative and scientific approach in modifying and reshaping the behaviour of the learners. Emphasis is given on self-discipline and intrinsic motivation through active, creative and constructive activities. It has tremendously helped teachers in tackling the problem of indiscipline.

14. Facilitating Context: Learning is based on context so generalizing learning to new contexts is not spontaneous but rather needs to be facilitated. Transfer of learning from one context to another, linking previous knowledge to present knowledge and to bridge the future knowledge based on present knowledge helps learners to develop insight of topics resulting in high order thinking skills. Educational psychology helps teachers by providing various theories and principles by which learners will be able to generalize learning to new contexts.

15. Socialization in Classroom: Socialization is a process whereby an individual learns to behave in accordance with social traditions and mores. Educational psychology helps in knowing and forming group dynamics, team work and leadership qualities among the learners. Mutual respect to everyone and environment that values individual learner efforts and encourages, motivates them to participate results in increased engagement and high academic achievement (Dallimore, Hertenstein and Platt, 2004) and (Pickens, 2007).

16. Professional Growth: Educational Psychology helps the teacher to know about himself/herself, own behaviour pattern, personality characteristics, likes and dislikes, motivation, anxiety, conflicts, adjustment etc. Inside the classroom, educational psychology has enabled the teacher to achieve proper conditioning of learners by achieving and directing classroom activities as learner centered. Educational psychologists explore innovations in the field of education and these innovations will bring about professional growth of the teacher. These are possible only when he possesses the knowledge of educational psychology. All this knowledge helps him in growing as a suqcessful and effective teacher.

\section{Conclusions}

Educational psychology has contributed considerably in the creation of the modern system of education. It has helped teachers and administrators to develop an impartial and democratic attitude towards learners and helps them into integrated personalities. Educational psychology is of prime importance in addressing the future needs of the education system as the complexities are increasing day by day so it is an effective way to cope up with them. Its role is central to know and deal about the problems related to the learners such as stages of development, to know about the learner, in fostering classroom environment, about individual differences, to identify children with special 
needs, tackling classroom problems, skills \& interest in teaching, effective methods of teaching, influence of heredity \& environment on the child, mental health of the child, procedure of curriculum making, guidance \& counselling, assessment \& evaluation, in maintaining positive creative discipline, educational psychology \& research, in facilitating context, socialization in classroom and professional growth, changing attitude and innovative thinking of teachers.

\section{References}

Ames, C.A. (1991). Motivation: What Teachers Need to Know. Teachers College Record, 9 (3), 409-422.

Blake, B., \& Pope, T. (2008). Developmental Psychology: Incorporating Piaget's and Vygotsky's Theories in Classrooms. Journal of Cross-Disciplinary Perspectives in Education, 1 (1), 59-67.

Bojuwoye, O., Moletsane, M., Stofile, S., Moolla, M., \& Sylvester, F. (2014). Learners' Experiences of Learning Support in Selected Western Cape Schools. South African Journal of Education, 34 (1), 1-15.

Cohen, E. (1994). Restructuring the Classroom: Conditions for Productive Small Groups. United Publications, New York, pp. 321-348.

Crombie, G., Pike, S.W., Silverthorn, N., Jones, A., \& Piccinin, S. (2003). Students' Perceptions of their Classroom Participation and Instructor as a Function of Gender and Context. The Journal of Higher Education, 74 (1), 51-76.

Dallimore, E.J., Hertenstein, J.H., \& Platt, M.B. (2004). Classroom Participation and Discussion Effectiveness: Student-Centered Strategies. Communication Education, 53

(1), 103-115.

De Lisi, R., \& Golbeck, S. L. (1999). Implications of Piagetian Theory for Peer Learning. In A. M. O'Donnell \& King, A. (Eds.), Cognitive perspectives on peer learning, Mahwah, NJ: Erlbaum, pp. 3-37.

Dunlosky, J., Rawson, A.K., Marsh, E.J., Nathan, M.J., \& Willingham, D.T. (2013). Improving Students' Learning with Effective Learning Techniques: Promising Directions from Cognitive and Educational Psychology. Psychological Science in the Public Interest, 14 (1), 4-58.

Fernald, L.D., \& Fernald, P.S. (2004). Nunn's Introduction to Psychology (fifth edition).

A.I.T.B.S Publishers \& Distributors, Delhi, pp. 53-56.

Jones, T.S. (2004). Conflict Resolution Education: The Field, the Findings and the Future. Conflict Resolution Quarterly, 22 (1-2), 233-267.

Kember, D., \& Leung, D.Y.P. (2006). Characterising a Teaching and Learning Environment Conducive to Making Demands on Students while not Making their Workload Excessive. Studies in Higher Education, 31 (2), 185-198.

Kumari, M.A.R., Sundari, R.S., \& Rao, D.B. (2006). Methods of Teaching Educational Psychology. Discovery Publishing House, Delhi, pp. 6-13.

Mangal, S.K. (2014). Essentials of Educational Psychology. PHI Learning Pvt. Ltd, New Delhi, pp. 616636.

Manichander, T. (2015). Psychology of Learners \& Learning. Laxmi Book Publications, Maharashtra, pp.14-18.

Mannivannan, M., \& Mani, M.N.G. (2010). Understanding Educational Psychology. Neelkamal Publications Pvt. Ltd, New Delhi, pp. 246-266.

Patel, N.V. (2003). A Holistic Approach to Learning and Teaching Interaction: Factors in the Development of Critical Learners. The International Journal of Educational Management, 17 (6/7), 272-284. 